\title{
ANTIBACTERIAL ACTIVITIES OF SOME ISOLATED ALGAE FROM SIWA OASIS-EGYPT
}

\author{
Abou El-Kheir, Wafaa, S. ${ }^{(1)}$; Farag, Afaf, H. $^{(1)}$; Yaakob, Hanona, S. ${ }^{(2)}$; \\ Darwish, M. A. ${ }^{(3)}$ and Moustafa, Yosra, E. ${ }^{(2)}$
}

1) Botany Department, Faculty of Women for Arts, Science and Education, Ain Shams University 2) Medicinal and Aromatic Plants Department, Desert Research Centre 3) Fertilization Technology Department, National Research Centre

\begin{abstract}
In compliance to the recent surveys on algal species and their potentials to produce biologically active natural products, collection of algae were carried out during summer 2014 from five water habitats in Siwa Oasis. Three common microalgal pure isolates including one green alga Chlorella vulgaris and two blue green algae Chroococcus turgidus and Phormidium tenue were obtained using BG11, Basal Bold and Zarrouk media. The methanolic extracts of the three algal species were tested for the antibacterial activity against eight human pathogenic bacteria Enterococcus sp., Staphylococcus aureus, Acinetobacter baumannii, Escherichia coli, Klebsiella pneumonia, Proteus sp., Pseudomonas aeruginosa and Salmonella tyhphi using the agar well diffusion method. The results revealed that Phormidium tenue showed the highest promising antibacterial activity so it was choosed for successive extraction by using petroleum ether, ethylacetate, $80 \%$ methanol and water solvents. Among the tested solvents the ethyl acetate successive extract showed the highest antibacterial activity. Results of some chromatographic investigations for the ethyl acetate extract indicated that the phenolic compounds were the main components. High performance liquid chromatography (HPLC) technique was used for qualitative and quantitative analysis of the bioactive phenolic compounds. It resulted in identification of 22 phenolic compounds with different concentrations ranging from 1755.2 to10.425 $\mu^{-1}$ for ethyl vanillate and catechol compounds, respectively.
\end{abstract}

Key words: Algae isolation, algal extract, antibacterial activity, human pathogenic bacteria, High performance liquid chromatography (HPLC). 
J. Environ. Sci.

Institute of Environmental Studies and Research - Ain Shams University

\section{INTRODUCTION}

Extensive worldwide search is presently undergoing to find novel therapeutically cheaper alternatives for natural products which can be used in the preparation of drugs (Mayer et al., 2005 and Cardozo et al., 2007). Following the glow of the new vision and the greater interest to the pivotal role played by algae and their healing potency, this research work was achieved on some local aquatic fresh water microalgae isolated from Siwa Oasis. Microalgae have been used for therapeutic applications for several years and represent aunique opportunity to discover novel metabolites. Many microalgal extracts were found to have antialgal (Hellio et al., 2002), antifouling (Bhadury and Wright, 2004), anti-allergic (Na et al., 2005), antiinflammatory (Abedin and Taha, 2008), anticoagulant (Dayong et al., 2008), antiviral (Kim and Karadeniz, 2011), anticancer (Kim et al., 2011), antioxidant (Devi et al., 2011) and antibacterial or antifungal (Jaritz et al., 2011) activities. It is worthwhile screening the bioactivity of the microalgal crude extracts for the antibacterial activity against some infectious human pathogenic bacteria. Bacterial infection causes high rate of mortality in human population and aquaculture organisms. For example, Salmonella sp. causes diarrhea and typhoid fever (Leven, 1987 and Jawetz et al., 1995). Escherichia coli, Staphylococcus aureus and Pseudomonas aeruginosa cause diseases like mastitis, abortion, respiratory complications including some life threatening illness (Boyd, 1995). According to recent reports of the World Health Organization (WHO) it is mandatory to develop safe, nontoxic and efficient anti-bacterial agents of valuable practice in pharmacology and to 
diminish side effects of antibiotics as the latter could raise toxicities and serious threatened conditions in some cases. On the other hand, preventing disease outbreaks or treating the diseases with drugs or chemicals alone may not be sufficient to tackles these problems as the microorganisms develop resistance against the applied chemical drugs (Walsh, 2003). The first investigation on antibiotic activity of algae was carried out by Pratt et al., (1944). Many studies have been established to prove the antimicrobial effect of metabolites extracted from algal species especially those derived from blue green algae (Zulpa et al., 2003; Abedin and Taha, 2008). Many investigators have reported antibacterial activities of microalgae as due to fatty acids (Cooper et al., 1983; Findlay and Patil, 1984). Antibacterial activity of volatile extracts of Spirulina platensis have been studied by Ozdemir et al., (2004). El-Sheekh et al. (2006) showed that phenolic compound from Nostoc muscorum exhibited antagonistic activity against Gram +ve and Gram -ve bacteria.

This study aims to: 1- Isolation and purification of some common microalgal species from one of the Egyptian desert oases as a natural source for the therapeutic application. 2-Studying the antibacterial activity of the algal extracts against some infectious human pathogenic bacteria. 3Analyzing the main bioactive components of the most potent algal extracts.

\section{MATERIAL AND METHODS}

The study area: Siwa Oasis is considered as one of the seven major important depressions in the Western Desert of Egypt. Geographically it is situated in between latitude $\left(29^{\circ} 12^{\prime} 11.4156^{\prime \prime} \mathrm{N}\right)$ and longitude $\left(25^{\circ} 31^{\prime}\right.$ 
10.3620" E). It is about $306 \mathrm{~km}$ southwest Marsa Matrouh and $60 \mathrm{~km}$ east of Libyan border and about $400 \mathrm{~km}$ west of Bahariya Oasis (El Hossary, 2013).

1) Sampling: Five field water samples were collected (in summer 2014) from five stations that are located in Siwa Oasis including:

1. Ain Cleopatra at $\left(29^{\circ} 11^{\prime} 48^{\prime \prime} \mathrm{N}, 25^{\circ} 32^{\prime} 59^{\prime \prime} \mathrm{E}\right)$.

2. Haudh Cleopatra at $\left(29^{\circ} 11^{\prime} 47^{\prime \prime} \mathrm{N}, 25^{\circ} 32^{\prime} 56^{\prime \prime} \mathrm{E}\right)$.

3. Ain Fetnas at $\left(29^{\circ} 11^{\prime} 38^{\prime \prime N}, 25^{\circ} 28^{\prime} 56^{\prime \prime} \mathrm{E}\right)$.

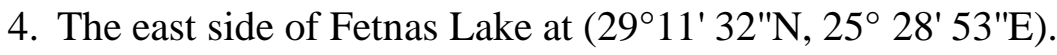

5. Private farm's well (reservoir) at (N: 29¹0' 14", E: $\left.25^{\circ} 31^{\prime} 57^{\prime \prime}\right)$.

Clean plastic bottles with a capacity of $2 \mathrm{~L}$ in duplicates were used. Collections were made for the top and bottom of the water for each location.

2) Cultivation of algal samples: Under aseptic conditions cultivation was performed as follows; inoculating samples $(10 \mathrm{ml})$ in $250 \mathrm{ml}$ Erlenmeyer flasks each containing $150 \mathrm{ml}$ of the sterile liquid medium such as; (BG11) media with A5(micronutrients mixture) (Stanier et al., 1971) for green and blue green algae, Basal Bold media (BBM) (Bischoff and Bold, 1963) for green algae and Zarrouk media (Z) (Zarrouk, 1966) for blue green algae. Each media incubated under the favorable growth conditions of natural laboratory (room temperature and natural day light).

3) Isolation and Purification: Three monocultures of certain common algal species were obtained from private farm's well, Ain Fetnas and Haudh Cleopatra stations using serial dilution procedures recommended by Jurgensen and Davey (1968). Algal species were morphologically examined 
using the light microscope. They were identified according to the key of Desikachary, (1959) and Prescott, (1978).

4) Propagation:The three purified cultures of microalgal species (Chlorella vulgaris, Chroococcus turgidus and Phormidium tenue) were prepared for biomass propagation using closed system of BG-11 growth media with increasing the volume gradually $(250 \mathrm{ml}, 1 \mathrm{~L}, 5 \mathrm{~L}$ and $15 \mathrm{~L})$. Heterotrophic growth was performed by $6 \mathrm{mM}$ sodium acetate (Kobayashi et al., 1993) light was provided by one side of light bank (40 Wx5 white fluorescent day light lamps $/ 120 \mathrm{~cm})$. Aeration was done by compressed air. The cultures were incubated for 21 days at room temperature $\left(25-28^{\circ} \mathrm{C}\right)$.

5) Harvesting and drying:The fresh biomass was collected after filtration and centrifugation at $5200 \mathrm{rpm} / 5 \mathrm{~min}$. to obtain pure algal cell mass for each isolate then air dried in oven at $40{ }^{\circ} \mathrm{C}$. Dry biomass ground by mortar pestele and kept in cleaned bottles at room temperature $\left(25-28^{\circ} \mathrm{C}\right)$.

6) Preparations of total alcoholic algal extract: $2.5 \mathrm{~g}$ dried algal biomass was added to $50 \mathrm{ml} 80 \%$ methanol and kept under room temperature for 48 hours and rapidly stirred using glass rod every 8 hours, then the extracts were filtered. The filtrate was concentrated under reduced pressure at $40^{\circ} \mathrm{C}$ according to Lim and Darah (2013).

7) Antibacterial activity of crude methanolic extracts: According to Holder and Boyce (1994) the agar well-diffusion method was followed to determine the antibacterial activity. Nutrient Agar (NA) plates were swabbed (sterile cotton swabs) with 8 hour old - broth culture of respective human pathogenic bacteria Acintobacter baumannii, Enterococcus sp., Escherichia coli, Klebsiella pneumonia, Proteus sp., Pseudomonas aeruginosa, 
Salmonella typhi and Staphylococcus aureus. Bacterial strains were kindely provided from Specialized Hospital, Ain Shams University. Wells (10mm diameter) were made in each of these plates using sterile corkborer. Stock solution of each algal extract was prepared by re-dissolving in dimethyl sulphoxide (DMSO) at a concentration of $50 \mathrm{mg} / \mathrm{ml}$ algal extacts. About 100 $\mu l$ of algal extract were added using sterile syringe into the wells and allowed to diffuse at room temperature for $2 \mathrm{hrs}$. Control experiments comprising inoculums without algal extract were set up. The plates were incubated at $37^{\circ} \mathrm{C} / 18-24 \mathrm{~h}$. The diameter of the inhibition zone $(\mathrm{mm})$ was measured.

8) Successive extraction of Phormidium tenue: The Phormidium tenue isolate which gave the promising antibacterial activity results were successively extracted. The dried algal powders (20gm) were successively extracted using serial exhaustive extraction method (Das et al., 2010) using petroleum ether, ethylacetate, $80 \%$ methanol and water solvents. Each extract was concentrated to dry and kept for further investigation. Extracts of different solvents were collected separately into dry clean beakers, after that they were recovered from the solvents by evaporation in a rotary evaporator at $40^{\circ} \mathrm{C}$.

9) Antibacterial activity of successive extracts: Prepared successive extracts of Phormidium tenue were tested against the selected pathogenic bacteria. Using the Agar well-diffusion technique as applied previously to detect the most active successive extract of the algal isolate.

10) Chemical analysis of the most potent successive algal extract: According to some chromatographic investigations it was found that 
phenolics were the main active compounds of the ethyl acetate successive extract of Phormidium tenue (Harbone, 1984 and Mallikharjuna et al., 2007). Separation and determination of the phenolics were performed by reverse phase HPLC (RP-HPLC)/diode array detection (DAD) (Hewlett Packard 1050) using a column Alltima C18, $5 \mu \mathrm{m}(150 \mathrm{~mm} X 4.6 \mathrm{~mm}$ id) with a guard column Alltima C18, $5 \mu \mathrm{m}$ (Alltech). The solvent system used was a gradient of A (acetic acid 2.5\%), B (acetic acid 8\%) and C (acetonitrile). The best separation was obtained with the following gradient: at $0 \mathrm{~min}, 5 \% \mathrm{~B}$; at 20 $\mathrm{min}, 10 \% \mathrm{~B}$; at $50 \mathrm{~min}, 30 \% \mathrm{~B}$; at $55 \mathrm{~min}, 50 \% \mathrm{~B}$; at $60 \mathrm{~min}, 100 \% \mathrm{~B}$; at $100 \mathrm{~min}, 50 \% \mathrm{~B}$ and $50 \% \mathrm{C}$; at110min, 100\% C until 120min. The solvent flow rate was $1 \mathrm{ml} \mathrm{min}-1$ and separation was performed at $35^{\circ} \mathrm{C}$. The volume injected was 10ul. Phenolic compounds were assayed by external standard calibration at $280 \mathrm{~nm}$ and expressed in $\mathrm{mgg}{ }^{1}$ dry matter. The identification of phenolic compounds was accomplished by comparison of their retention times with those of pure standards.

\section{RESULTS}

Isolation and Purification:The three obtaind pure microalgal species were identified as Chlorella vulgaris, Chroococcus turgidus and Phormidium tenue which were isolated from private farm's well, Ain Fetnas and Haudh Cleopatra stations, respectively.

Antibacterial effect of the methanolic algal extracts on the growth pathogenic bacteria (Table1):

i. Chlorella vulgaris methanolic extract inhibited the growth of Salmonella typhi and Staphylococcus aureus and the recorded inhibition zones were 
(26mm and 19mm); respectively. While other pathogenic bacteria were resistant to it (Table1).

ii. Chroococcus turgidus methanolic extract inhibited the growth of Salmonella typhi and Acinetobacter baumannii and the recorded inhibition zones were $(\mathbf{2 7} \mathbf{m m}$ and $\mathbf{1 7} \mathbf{m m})$; respectively. While other pathogenic bacteria were resistant to it (Table1).

iii.Phormidium tenue methanolic extract inhibited the growth of Salmonella typhi, Acinetobacter baumannii, Staphylococcus aureus, Escherichia coli and Klebsiella pneumonia and the recorded inhibition zones were $(30 \mathrm{~mm}, 28 \mathrm{~mm}, 27 \mathrm{~mm}, 18 \mathrm{~mm}$ and $17 \mathrm{~mm})$; respectively. While other pathogenic bacteria were resistant to it (Table1).

Table (1): The inhibition effect of the methanolic extract of Chlorella vulgaris, Chroococcus turgidus and Phormidium tenue on growth of human pathogenic bacteria.

\begin{tabular}{|l|c|c|c|}
\hline \multirow{2}{*}{ Blgal isolate } & \multicolumn{3}{|c|}{ Diameter of inhibition zone in (mm) } \\
\cline { 2 - 4 } & $\begin{array}{c}\text { Chlorella } \\
\text { vulgaris }\end{array}$ & $\begin{array}{c}\text { Chroococcus } \\
\text { turgidus }\end{array}$ & $\begin{array}{c}\text { Phormidium } \\
\text { tenue }\end{array}$ \\
\hline \hline Acinetobacter baumannii & $-\mathrm{ve}$ & 17 & 28 \\
\hline Enterococcus sp. & $-\mathrm{e}$ & $-\mathrm{e}$ & $-\mathrm{ve}$ \\
\hline Eschericiha coli & $-\mathrm{ve}$ & $-\mathrm{ve}$ & 17 \\
\hline Klebsiella pneumonia & $-\mathrm{ve}$ & $-\mathrm{ve}$ & 18 \\
\hline Pseudomonas aeruginosa & $-\mathrm{ve}$ & $-\mathrm{ve}$ & $-\mathrm{ve}$ \\
\hline Proteus sp. & $-\mathrm{ve}$ & $-\mathrm{ve}$ & $-\mathrm{ve}$ \\
\hline Salmonella typhi & 26 & 27 & 30 \\
\hline Staphylococcus aureus & 19 & $-\mathrm{v}$ & 27 \\
\hline
\end{tabular}


Antibacterial activity of successive extracts of Phormidium tenue on the growth of pathogenic bacteria:

i. Petroleum ether extract of Phormidium tenue showed antibacterial activity against Escherichia coli, Enterococcus sp. and Salmonella typhi and the recorded inhibition zones were $(\mathbf{2 3} \mathbf{m m}, \mathbf{2 2} \mathbf{m m}$ and $\mathbf{1 9 m m})$; respectively. While other pathogenic bacteria were resistant to it (Table 2)

ii. Ethyl acetate extract of Phormidium tenue showed antibacterial activity against Acinetobacter baumannii, Enterococcus sp., Klebsiella pneumonia, Salmonella typhi, Escherichia coli and Staphylococcus

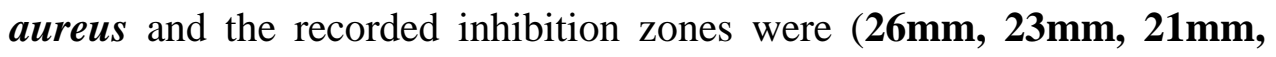
20mm, 20mm and $15 \mathrm{mmm}$ ); respectively. While other pathogenic bacteria were resistant to it (Table 2).

iii. Methanol extract: All selected pathogenic bacteria were resistant to the 80\% methanol extract of Phormidium tenue except Escherichia coli. The recorded inhibition zone was $(\mathbf{1 5 m m})$ (Table $\mathbf{2})$.

iv. Water extract: All selected pathogenic bacteria were resistant to the water extract of Phormidium tenue (Table 2). 
Table (2): The inhibition effect of the successive extracts of Phormidium tenue on the growth of pathogenic bacteria

\begin{tabular}{|l|c|c|c|}
\hline \multirow{2}{*}{ Blgal Extract } & \multicolumn{3}{|c|}{ Diameter of inhibition zone in (mm) } \\
\cline { 2 - 4 } & $\begin{array}{c}\text { Petroleum } \\
\text { ether extract }\end{array}$ & $\begin{array}{c}\text { Ethyl acetate } \\
\text { extract }\end{array}$ & $\begin{array}{c}\text { Methanol 80\% } \\
\text { extract }\end{array}$ \\
\hline \hline Acinetobacter baumannii & $-\mathrm{ve}$ & 26 & $-\mathrm{ve}$ \\
\hline Enterococcus sp. & 22 & 23 & $-\mathrm{ve}$ \\
\hline Escherichia coli & 23 & 20 & 15 \\
\hline Klebsiella pneumonia & $-\mathrm{ve}$ & 21 & $-\mathrm{ve}$ \\
\hline Pseudomonas aeruginosa & $-\mathrm{ve}$ & $-\mathrm{ve}$ & $-\mathrm{ve}$ \\
\hline Proteus sp. & $-\mathrm{ve}$ & $-\mathrm{ve}$ & $-\mathrm{ve}$ \\
\hline Salmonella typhi & 19 & 20 & -ve \\
\hline Staphylococcus aureus & $-\mathrm{ve}$ & 15 & $-\mathrm{ve}$ \\
\hline
\end{tabular}

\section{Identification of phenolic compounds using HPLC technique:}

The qualitative and quantitative estimation of the phenolic compounds of Phormidium tenue ethylacetate successive extract were achieved using the high performance liquid chromatography (HPLC) technique, where each compound was seperated, identified using authentic pattern and determined its concentration. The seperated and identified compounds were Ethyl vanillate, Catechein, Alpha-Coumaric acid, Epicatachin, Chlorogenic acid, 4Amino-benzoic acid, Pyrogallol, Cinnamic acid, Coumarin, Ellagic acid, Caffene, P-OH- benzoic acid, Ferulic acid, Caffeic acid, Benzoic acid, Isoferulic acid, Protocatchuic acid, 3,4,5-methoxy-Cinnamic acid, P-coumaric acid, Gallic acid, Salycilic acid and Catechol. The concentration of ethyl vanilliate showed the maximum value (1755.2 ppm). While catechol showed the minimum value (10.4 ppm) (Table 3). 
Table (3): Phenolic composition of the ethyl acetate successive extract of Phormidium tenue using HPLC.

\begin{tabular}{|l|c|}
\hline \multicolumn{1}{|c|}{ Phenolic compounds } & Concentration in ppm \\
\hline \hline Ethylvanillate & 1755.2 \\
\hline Catechein & 627.9 \\
\hline Alpha-coumaric acid & 429.2 \\
\hline Epicatachin & 325.41 \\
\hline Chlorogenic acid & 289.45 \\
\hline 4-Amino-benzoic acid & 283.57 \\
\hline Pyrogallol & 278.68 \\
\hline Cinnamic acid & 278.68 \\
\hline Coumarin & 231.87 \\
\hline Ellagic acid & 227.47 \\
\hline Caffene & 189.6 \\
\hline P-OH- benzoic acid & 145.74 \\
\hline Ferulic acid & 137.68 \\
\hline Caffeic acid & 136.13 \\
\hline Benzoic acid & 114.88 \\
\hline Iso-ferulic acid & 89.776 \\
\hline Protocatchuic acid & 57.18 \\
\hline 3,4,5-methoxy-cinnamic acid & 44.937 \\
\hline P-coumaric acid & 42.058 \\
\hline Gallic acid & 29.934 \\
\hline Salycilic acid & 14.392 \\
\hline Catechol & 10.425 \\
\hline
\end{tabular}

\section{DISCUSSION}

Usage of commercial antibiotics for human disease treatment produces undesirable side effects. Cell extracts and active constituents of various algae may be potential bioactive compounds of interest in the pharmaceutical industry (Rodrigues et al., 2004). In the present study the results showed that the methanolic extracts of the three tested algae Chlorella vulgaris, 
Chroococcus turgidus and Phormidum tenue had an antibacterial activity against some of the selected human pathogenic bacteria Acintobacter baumannii, Enterococcus sp., Escherichia coli, Klebsiella pneumonia, Proteus sp., Pseudomonas aeruginosa, Salmonella typhi and Staphylococcus aureus (Table 1).

Recorded results of inhibition zone diameters of Phormidium tenue methanolic extract revealed that it affected on five of selected tested pathogenic bacteria including one Gram-positive bacteria Staphylococcus aureus $(27 \mathrm{~mm})$ and four Gram-negative bacteria Salmonella typhi (a gastrointestinal tract (GIT) infectious bacteria) $(30 \mathrm{~mm})$, Acinetobacter baumannii (28mm), Klebsiella pneumonia (18mm) and Escherichia coli $(17 \mathrm{~mm})$. These results are in agreement with the results obtained by Sethubathi and Prabu (2010) who found that the aqueous crude extract of Phormidium sp. had an antibacterial activity against human pathogenic bacteria such as Streptococcus mutants, Staphylococcus aureus, Pseudomonas aeruginosa, Bacillus subtilis and Klebsiella pneumoniae. Also, these results coordinate with the results obtained by Al-Wathnani et al. (2012) who found that Phormidium autumnale showed a wide inhibition zone (about $25 \mathrm{~mm}$ ) against Shigella sonnei (a gastrointestinal tract (GIT) infectious bacteria).

In the current recorded results of inhibition zone diameters of Chroococcus turgidus methanolic extract revealed that it affected on two Gram-ve pathogenic bacteria only, Salmonella typhi $(27 \mathrm{~mm})$ and Acinetobacter baumannii $(17 \mathrm{~mm})$ but with diameter of inhibition zones less 
than that of the coressponding inhibition zones of Phormidium tenue against Salmonella typhi $(30 \mathrm{~mm})$ and Acinetobacter baumannii $(28 \mathrm{~mm})$. These results are in agreement with the results obtained by Chinnu et al. (2014) who found that the methanolic extract of Chroococcus turgidus had a good activity against the tested bacteria Staphylococcus aureus (13mm), Pseudomonas aeruginosa (8mm) and Salmonella typhi $(8 \mathrm{~mm})$. In another report Chroococcus disperses exhibited widespread spectrum of antimicrobial activities (Younes et al., 2007). It was reported the methanolic extract of $C$. turgidus exhibited positive inhibition (92.6\%) against E. coli (Abdo et al., 2012) but this was in contrast with the present result which showed negative inhibition.

These two results of Phormidium tenue and Chroococcus turgidus revealed the potential of the blue green algal extract.

Recorded results of inhibition zone diameters of Chlorella vulgaris methanolic extract revealed that it affected on two pathogenic bacteria only, one was Gram +ve Staphylococcus aureus $(19 \mathrm{~mm})$ and the other was Gram ve Salmonella typhi $(26 \mathrm{~mm})$, also with a diameter of inhibition zones less than that of the coressponding inhibition zones of Phormidium tenue against Salmonella typhi $(30 \mathrm{~mm})$ and Staphylococcus aureus $(27 \mathrm{~mm})$. These results are in agreement with the results obtained by Sanmukh et al. (2014) who found that Chlorella sp. extract had a high effect against the pathogenic bacteria (Streptococcus pneumoniae, Staphylococcus aureus, Escherichia coli and Salmonella sp.). 
In the current result Phormidium tenue ethyl acetate successive extract showed the maximum recorded diameter of inhibition zones against Enterococcus sp. (23mm) and the gastrointestinal tract (GIT) infectious bacteria Salmonella typhi $(20 \mathrm{~mm})$, it was the only one affected on Acinetobacter baumannii (26mm), Klebsiella pneumonia $(21 \mathrm{~mm})$ and Staphylococcus aureus (15mm), also it affected on Escherichia coli but with diameter of inhibition zone $(20 \mathrm{~mm})$ less than that of the petroleum ether successive extract $(23 \mathrm{~mm})$ (Table 2). These results are in agreement with the results obtained by Khairy and El-Kassas (2010) who found that the ethylacetate extract of the three tested blue green algae Anabaena flosaquae, Anabaena variabilis and Oscillatoria angustissima notably inhibited nearly the whole tested eight bacteria Bacillus subtilis, Bacillus cereus, Staph. aureus Salmonella faecalis, E. coli P.aeruginosa, Aeromonas hydrophila, Vibrio fluvialis. Also, these results are in agreement with the results obtained by Abdel-Raouf and Ibraheem (2008) who reported the antibiotic activity of the ethyl acetate extract of two Anabaena species against four fish pathogenic bacteria Aeromonas spp.

In the present result it was found that phenolic compounds were the main active compounds in the ethylacetate successive extract.

These results are in agreement with the results obtained by Ouattara et al. (2011) who reported that the phenolic contents are active as antibacterial agents against different types of microorganisms like Salmonella typhi.

In the present study the HPLC analysis of the ethylacetate successive extract of Phormidium tenue resulted in the identification of 22 phenolic 
compounds which were ethyl vanillate, catechein, alpha-coumaric acid, epicatachin, chlorogenic acid, 4-amino-benzoic acid, pyrogallol, cinnamic acid, coumarin, ellagic acid, caffene, p-OH- benzoic acid, ferulic acid, caffeic acid and benzoic acid, Iso-ferulic acid, protocatchuic acid, 3,4,5-methoxycinnamic acid, p-coumaric acid, gallic acid, salycilic acid and catechol with different concentrations ranging from 1755.2 to10.425 $\mathrm{Mgg}^{-1}$ (Table 3). These results are in agreement with the results obtained by Ijaz and Hasnain (2016) who found that cyanobacterial strains showed high potential as a good source of phenolic compounds which could be beneficial for food, cosmetic and pharmaceutical industries. Also, these results are coordinate with the result obtained by Abd El-Baky et al. (2009) who found that Gallic, chlorogenic, cinnamic, p-OH benzoic, quimic, caffeic, vanillic and ferulic acids were the most abundant constituents of phenolic acids of Spirulina maxima.

\section{The Economic values of some identified phenolic compounds (Table3):}

Ethyl Vanillate: (vanillic acid ethyl ester): It is a strong hydrogen peroxide scavenger, an antioxidant agent, reduce the need for phototherapy in the treatment of vitiligo by improving repigmentation (Namazi, 2015).

Vanillic acid: Protective effect of VA against hyperinsulinemia, hyperglycemia and hyperlipidemia is through decreasing hepatic nonestrified fatty acid accumulation, alleviating hepatic inflammation (Chang et al., 2015).

Chlorogenic acid: Antioxidant (Jing et al., 2013), anticancer for colon (Thurow, 2012). 
Pyrogallol: Antifungal against Candida albicans (Ramage et al., 2014).

Cinnamic acid: Inhibitory effects of cinnamic acid on melanin biosynthesis in skin (Kong et al., 2008).

Coumarines: treatment of prostate cancer, renal cell carcinoma and leukemia and side effects caused by radiotherapy (Rohini and Srikumar, 2014).

Gallic acid: has high antioxidant capacity, significantly higher than any other antioxidant and about five times higher than vitamin $\mathrm{c}$ juice of apple (Sakagami, et al., 1997).

\section{CONCLUSION}

Phormidium tenue was observed to exhibit a high antibiotic activity against the tested human pathogens. Among the tested extracts the ethylacetate extract of Phormidium tenue showed as a promising and potential solvent for the extraction of antimicrobial compounds. Phytochemical analyses showed that the phenolic compounds may be attributed to its antibacterial activity. Further analysis of the active compound from the alga might lead to a potent therapeutic agent.This study enables to pave a way to discover a new drug and field trials are to be needed with proper licencing producers.

\section{REFERENCES}

Abd El-Baky, H.H.; El Baz, F.K. and El-Baroty, G.S. (2009). Production of phenolic compounds from Spirulina maxima microalgae and its protective effects in vitro toward hepatotoxicity model. African Journal of Pharmacy and Pharmacology, 3(4),133-139. 
Abdel-Raouf, N. and Ibraheem, B.M.I. (2008). Antibiotic activity of two Anabaena species against four fish pathogenic Aeromonas species. African Journal of Biotechnology, 7(15), 2644-2648.

Abdo, S.M.; Hetta M.H.; Samhan, F.A.; El Din, R.A.S. and Ali, G.H. (2012). Phytochemical and antibacterial study of five fresh water Algal Species. Asian Journal of Plant Sciences, 11(3), 109-116.

Abedin R.M.A. and Taha H.M. (2008). Antibacterial and antifungal activity of cyanobacteria and green microalgae. Global Journal of Biotechnology and Biochemistry Research, 3,22-31.

Al-Wathnani, H.A.; Ara,I;; Tahmaz, R.R. and Bakir, M.A. (2012). Antibacterial activities of the extracts of cyanobacteria and green algae isolated from desert soil in Riyadh, Kingdom of Saudi Arabia. African Journal of Biotechnology, 11(38), 9223-9229.

Bhadury P. and Wright C.P. (2004). Exploitation of marine algae: biogenic compounds for potential antifouling application. Planta, 219,561578.

Bischoff, H.W. and Bold, H.C. (1963). Phycological Studies IV. Some Soil Algae From Enchanted Rock and Related Algal Specie. University of Texas, Austin, 6318, 1-95.

Boyd, R.C. (1995). Basic Medical Microbiology. Little Brown Company, Boston. Fifth edition.

Cardozo, K.H.M.; Guaratini, T.; Barros, M.P.; Falcáo, V.R., Tonon; A.P., Lopes, N.P., Campos, S.; Torres, M.A.; Souza, A.O.; Colepicolo, P. and Pinto, E. (2007). Metabolites from algae with economical impact. Comparative Biochemistry and Physiology, 146(1), 6078.

Chang, W.C.; Wu, J.S.B.; Chen, C.W.; Kuo, P.L.; Chien, H.M.; Wang, Y.T. and Shen, S.C. (2015). Protective effect of vanillic acid against hyperinsulinemia, hyperglycemia and hyperlipidemia via alleviating hepatic insulin resistance and inflammation in HighFat Diet (HFD)-fed rats. Nutrients, 7(12), 9946-9959. 
Chinnu, K.; Muthukumaran, M.; Mukund, S.; and Sivasubramanian, V. (2014). Studies on value added bio-chemicals of Chroococcus turgidus. International Journal of Institutional Pharmacy and Life Sciences 4(6), 75-92.

Cooper, S.; Battat, A.; Marot, P. and Sylvester, M. (1983). Production of antibacterial activities by two Bacillariophyceae grown in dialysis culture. Canadian Journal of Microbiology, 29, 338-341.

Das, K.; Tiwari, R.K.S and Shrivastava, D.K. (2010). Techniques for evaluation of medicinal plant products as antimicrobial agent: Current methods and future trends. Journal of Medical Plants Research, 4(2), 104-111.

Dayong, S.; Jing L.; Shuju, G.; and Lijun, H. (2008). Antithrombotic effect of bromophenol, the alga-derived thrombin inhibitor. Journal of Biotechnology, 136, 577-588.

Desikachary, T.V. (1959). Cyanophyta. Indian Council of Agricultural Research, New Delhi, 685 P.

Devi, G.K.; Manivannan, K.; Thirumaran, G.; Rajathi F.A.A. and Anantharaman, P. (2011). In vitro antioxidant activities of selected seaweeds from Southeast coast of India. Asian Pacific Journal of Tropical Medicine, 4, 205- 211.

El Hossary, M. F. (2013). Investigating the development challenges to Siwa Oasis, Northwestern Desert Egypt. New York Science Journal, $6(4), 55-61$.

El-Sheekh, M.M.; Osman, M.E.H.; Dyab, M.A.and Amer, M.S. (2006). Production and characterization of antimicrobial active substance from the cyanobacterium Nostoc muscorum. Environmental Toxicology and Pharmacology, 21, 42-50.

Findlay, J. A. and Patil, A. D. (1984). Antibacterial constituents of the diatom Navicula delognei. Journal of Natural Products. 47: 815-818.

Harborne, J.B. (1984). Phytochemical Methods A Guide to Modern Techniques of Plant Analysis, $2{ }^{\text {nd }}$ Edition: Chapman and Hall Ltd. New Fetterlane, London, New York. P.142-150. 
Hellio, C., Berge, J. P., Beaupoil, C., Le Gal, Y., Bourgougnon, N. (2002). Screening of marine algal extracts for anti-settlement activities microalgae and macroalgae. Biofouling. 18, 205-215.

Holder, I.A. and Boyce, S.T. (1994). Agar well diffusion assay testing of bacterial susceptibility to various antimicrobials in concentrations non-toxic for human cells in culture. Burns, 20, 426-429.

Ijaz, S. and Hasnain, S. (2015). Antioxidant potential of indigenous cyanobacterial strains in relation with their phenolic and flavonoid contents. Natural Product, 30(11), 1297-300.

Jaritz, N.B.M.; Solis, D.R.P.; Leon, F.S.L.R. and Ramírez, R.R. (2011). Antimicrobial activity of aqueous and methanolic extracts from Arthrospiramaxima. Science against microbial pathogens: communicating current research and technological advances, A Méndez Vilas (Ed.) FORMATEX. pp 1267- 1271.

Jawetz, E.; Mellnick, J.L.and Adelberg, E.A. (1995). Review of Medical Microbiology, 20th Edition. Applellation Lange Norwalk, Connecticut, 139-218.

Jin, G.H.; Liu, Y.; Jin, S.Z.; Liu, X.D. and Liu, S.Z. (2007). UVB induced oxidative stress in human keratinocytes and protective effect of antioxidant agents. Radiation and Environmental Biophysics, 46, $61-68$.

Jing, G.; Huang, H.; Yang, B.; Li, J.; Zheng, X. and Jiang, Y. (2013). Effect of pyrogallol on the physiology and biochemistry of litchi fruit during storage. Chemistry Central Journal, 7:19.

Jurgensen, M.F. and Davey, C.B. (1968). Nitrogen-fixing blue-green algae in acid forest and nursery soils. Canadian Journal of Microbiology, $14,1179-1183$.

Khairy, H.M. and El-Kassas, H.Y.(2010). Active substance from some blue green algal species used as antimicrobial agents. African Journal Biotechnology, 9(19), 2789-2800.

Kim, S.K. and Karadeniz, F. (2011). Anti-HIV. Activity of extracts and compounds from marine algae. Advances in Food and Nutrition Research, 64, 255-265. 
Kim, S.K.; Thomas, N.V. and Li, X. (2011). Anticancer compounds from marine macroalgae and their application as medicinal foods, Advances in Food and Nutrition Research, 64, 213-224.

Kobayashi, M.; Kakizono, T.and Nagai,S. (1993). Enhanced carotenoid biosynthesis by oxidative stress in acetate-induced cyst cells of a green unicellular alga, Haematococcus pluvialis. Applied and Environmental Microbiology 59, 867 \pm 873

Kong, Y.H.; jo, Y.; Cho, C.W.; Son, D.; Park, S.; Rho, J. and Choi, S.Y. (2008). Inhibitory effects of cinnamic acid on melanin biosynthesis in skin. Biological and Pharmaceutical Bulletin. 31(5), 946-8.

Leven, M.M. (1987). Escherichia coli that causes diarrhea: Enterotoxigenic, enteropathogenic, enteroinvasive, enterohemorrhagic and enteroadherent. Journal of Infectious Diseases, 155, 41-47.

Lim, S.H.; Darah, I. (2013). Assessment of anticandidal activity and cytotoxicity of root extract from Curculigo latifolia on pathogenic Candida albicans. Journal of Medical Sciences, 13,193-200.

Mayer, A.M.S.; Hall, M.L.; Lynch, S.M.; Gunasekera, S.P.; Sennett, S.H. and Pomponi, S.A. (2005). Differential modulation of microglia superoxide anion and thromboxane $\mathrm{B} 2$ generation by the marine manzamines, BMC Pharmacology, 5, 6-18.

Mallikharjuna, P.B.; Rajanna, L.N.; Seetharam, Y.N. and Sharanabasappa, G.K. (2007). Phytochemical studies of Strychonos potatorum L.f.-A medicinal plant. European Journal of Chemistry, 4, 510-518.

Na, H.J.; Moon, P.D.; Lee, H.J.; Kim, H.R.; Chae, H.J.; Shin, T.; Seo, Y.; Hong, S.H. and Kim, H.M. (2005). Regulatory effect of atopic allergic reaction by Carpopeltisaffinis. Journal of Ethnopharmacology,101, 43-48. 
Namazi, M.R. and Shotorbani, A.K. (2015). Evaluation of the efficacy of topical ethyl vanillate in enhancing the effect of narrow band ultraviolet B against vitiligo: A double blind randomized, placebo-controlled clinical trial. Iranian Journal of Medical Sciences, 40(6):478-84.

Ouattara, L.; Koudou, J.; Zongo, C.; Barro, N. and Savadogo, A.; Bassole, A. I.H.N.; Ouattara, A.S. and Alfred S. T. (2011). Antioxidant and antibacterial activities of three species of Lannea from Burkina Faso. Journal of Applied Sciences, 11,157-162.

Ozdemir, G.; Karabay, N.; Dolay, M. and Pazarbasi, B. (2004). Antibacterial activity of volatile extracts of Spirulina plantensis. Phytotherapy Research, 18(9), 754-757.

Pratt, R.; Daniel, T. C.; Eier, J. B., Gunnison; J. B.; Kumler, W. D.; Oneto, J. F., Strait, L.A.; Spoehr, H. A.; Hardin, G. J.; Milner, H. W.; Smith, H. and Strain, H. H. (1944). Chlorellin. An antibacterial substance from Chrolella. Science, 99, 351-352.

Prescott G.W. (1978). How to know the freshwater algae. $3^{\text {rd }}$ edition. Boston, (MA): McGraw Hill.

Ramage, G.; Robertson, S.N. and Williams, C. (2014). Strength in numbers: antifungal strategies against fungal biofilims. International Journal of Antimicrobial Agents, 43,114-20.

Rodrigues, E.; Tilvi, S.and Naik CG (2004). Antimicrobial activities of marine organisms collected off the coast of East India. Journal of Experimental Marine Biology and Ecology, 309, 121-127.

Rod Rohini, K. and Srikumar. P.S. (2014). Therapeutic role of coumarins and coumarin-related compounds. Thermodynamics and Catalysis, $5(2), 2-3$.

Sakagami, H.; Satoh, K.; Hatano, T.; Yoshida, T. and Okuda, T. (1997). Possible role of radical intensity and oxidation potential for gallic acid-induced apoptosis. Anticancer Research, 17, 377-380. 
Sanmukh, S.; Bruno, B.; Ramakrishnan, U.; Khairnar, K.; Swaminathan, S. and Paunikar, W. (2014). Bioactive compounds derived from microalgae showing antimicrobial activities. Journal of Aquaculture \& Research Development, 5, 224.

Sethubathi, B.V.G. and Prabu, A.V. (2010). Antibacterial Activity of Cyanobacterial Species from Adirampattinam Coast, Southeast Coast of Palk Bay. Current Research Journal of Biological Sciences. 2, 24-26.

Stanier, R.Y.; Kunisawa, R.; Mandel, M. and Cohen-Bazire, G. (1971). Purification and properties of unicellular blue-green algae (Order Chroococcales). Bacteriology Reviews. 35, 171-205.

Thurow, T. (2012). Effect of chlorogenic acid and neochlorogenic acid on human colon cancer cells. Food Science Undergraduate Honors Theses. Paper 2.

Walsh, C. (2003). Where will new antibiotics come from. Nature Reviews Microbiology, 1, 65-70.

Younes G.; Ameneh M.; Abdolali M.; Shadman S. and Mohammad H. M. (2007). Antifungal and antibacterial activity of the microalgae collected from paddy fields of Iran: Characterization of antimicrobial activity of Chroococcus dispersus. Journal of Biological Sciences, 7, 904-910.

Zarrouk, C. (1966). Contribution à l'étude d'une cyanophycée. Influence de divers' facteurs physiques et chimiques sur la croissance et la photosynthèse de Spirulina maxima. Ph.D. Thesis, Université de Paris, Paris.

Zulpa, G.; Zaccaro, M.C., Boccazzi, F.; Parada, J.L.and Storni, M. (2003). Bioactivity of intra and extracellular substances from cyanobacteria and lactic acid bacteria on "wood blue stain" fungi. Biological Control, 27, 345-348. 


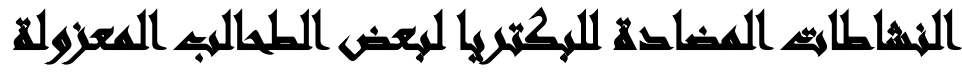

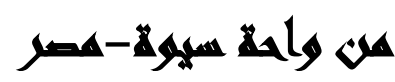

[1]

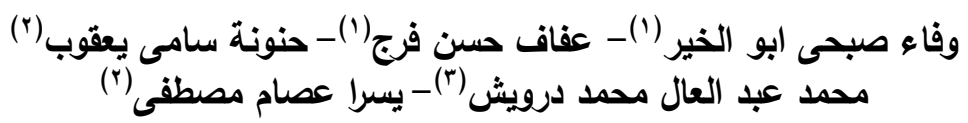

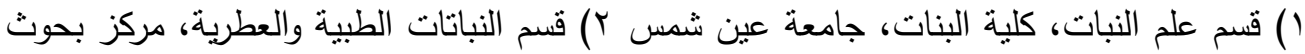
الصحراء، القاهرة ؟) قسم تكنولوجيا التسميد، المركز القومى للبحوث

\section{المستخلص}

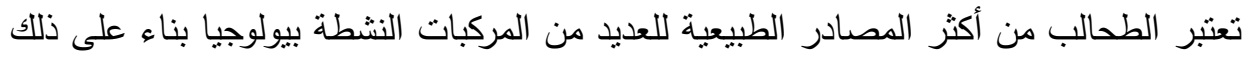

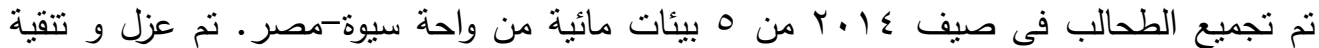
Chlorella vulgaris ثلاث أنواع من الطحالب الدقيقة الثائعة وهى نوع من الطحالب الخضراء

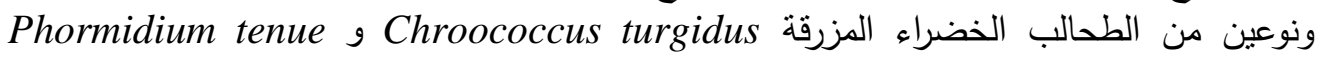

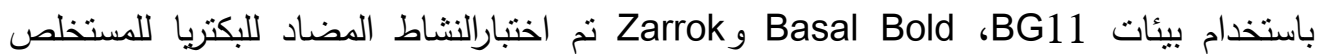

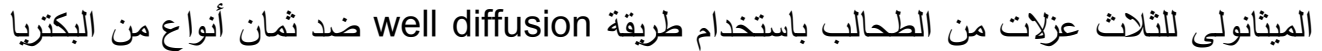

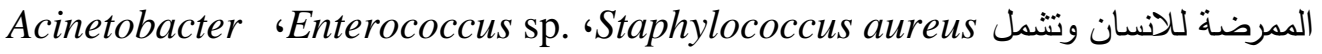
Proteus sp. ' Klebsiella pneumonia، Escherichia coli، baumannii

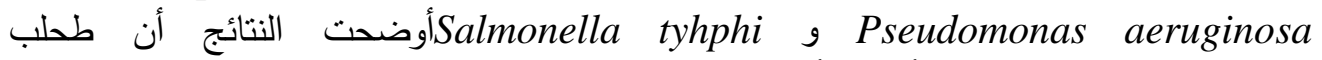
Phormidium tenue

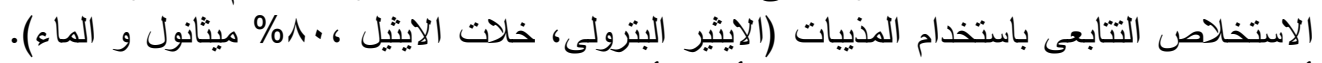

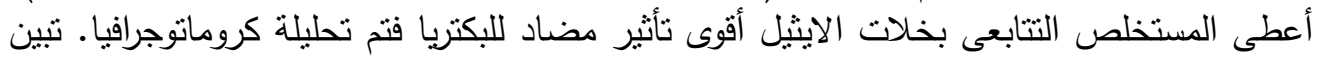
من النتائج ان المركبات الفينولية هى المركبات الفعالة الأكثر شيوعا فتم تعريفها وتقديرها باستخدام

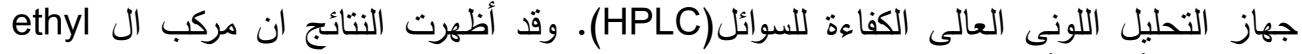
vanillate 